OPEN ACCESS

Edited by:

Ivan Zanoni,

Harvard Medical School,

United States

Reviewed by:

Marco A. Cassatella,

University of Verona, Italy

John P. Vasilakos,

3M Company at

St. Paul, United States

*Correspondence:

Shilpa Choksh

s.chokshi@researchinliver.org.uk

Specialty section:

This article was submitted to

Molecular Innate Immunity,

a section of the journal

Frontiers in Immunology

Received: 16 March 2017

Accepted: 10 May 2017

Published: 29 May 2017

Citation:

Phillips S, Mistry S, Riva A Cooksley H, Hadzhiolova-Lebeau T, Plavova S, Katzarov K, Simonova M, Zeuzem S, Woffendin C, Chen P-J,

Peng $C-Y$, Chang T-T, Lueth $S$,

De Knegt R, Choi M-S, Wedemeyer H, Dao M, Kim C-W, Chu H-C, Wind-Rotolo M, Williams $R$,

Cooney E and Chokshi S (2017)

Peg-Interferon Lambda Treatment

Induces Robust Innate and

Adaptive Immunity in Chronic

Hepatitis B Patients.

Front. Immunol. 8:621.

doi: 10.3389/fimmu.2017.00621

\section{Peg-Interferon Lambda Treatment Induces Robust Innate and Adaptive Immunity in Chronic Hepatitis B Patients}

\author{
Sandra Phillips ${ }^{1,2}$, Sameer Mistry,2, Antonio Riva ${ }^{1,2}$, Helen Cooksley, \\ Tanya Hadzhiolova-Lebeau ${ }^{3}$, Slava Plavova ${ }^{3}$, Krum Katzarov ${ }^{3}$, Marieta Simonova ${ }^{3}$, \\ Stephan Zeuzem ${ }^{4}$, Clive Woffendin ${ }^{5}$, Pei-Jer Chen ${ }^{6}$, Cheng-Yuan Peng ${ }^{7}$, \\ Ting-Tsung Chang ${ }^{8}$, Stefan Lueth ${ }^{9}$, Robert De Knegt ${ }^{10}$, Moon-Seok Choi ${ }^{11}$, \\ Heiner Wedemeyer ${ }^{12}$, Michael Dao ${ }^{13}$, Chang-Wook Kim ${ }^{14}$, Heng-Chen Chu' \\ Megan Wind-Rotolo ${ }^{16}$, Roger Williams ${ }^{1,2}$, Elizabeth Cooney ${ }^{6}$ and Shilpa Chokshi ${ }^{1,2 *}$
}

\begin{abstract}
IInstitute of Hepatology, Foundation for Liver Research, London, United Kingdom, ${ }^{2}$ Faculty of Life Sciences and Medicine, King's College London, London, United Kingdom, ${ }^{3}$ Clinic of Gastroenterology and Hepatology, Military Medical Academy, Sofia, Bulgaria, ${ }^{4}$ Johann Wolfgang, Goethe University Medical Center, Frankfurt, Germany, ${ }^{5}$ Oregon Clinical and Translational Research Institute, Portland, OR, United States, ${ }^{6}$ National Taiwan University Hospital, Taipei, Taiwan, ${ }^{7}$ China Medical University Hospital, Taichung, Taiwan, ${ }^{8}$ National Chen Kung University Hospital, Tainan, Taiwan, ${ }^{9}$ University of Hamburg, Hamburg, Germany, ${ }^{10}$ Erasmus University, Rotterdam, Netherlands, ${ }^{11}$ Sungkyunkwan University, Seoul, South Korea, ${ }^{12}$ Hannover Medical School, Hannover, Germany, ${ }^{13}$ Precision Diagnostic Laboratory, Santa Ana, CA, United States, ${ }^{14}$ The Catholic University of Korea, Seoul, South Korea, ${ }^{15}$ Tri-Service General Hospital, Taipei, Taiwan, ${ }^{16}$ Research and Development, Bristol-Myers Squibb, Wallingford, CT, United States
\end{abstract}

IFN-lambda (IFN $\lambda$ ) is a member of the type III IFN family and is reported to possess anti-pathogen, anti-cancer, and immunomodulatory properties; however, there are limited data regarding its impact on host immune responses in vivo. We performed longitudinal and comprehensive immunosurveillance to assess the ability of pegylated (peg)-IFN $\lambda$ to augment antiviral host immunity as part of a clinical trial assessing the efficacy of peg-IFN $\lambda$ in chronic hepatitis $B(\mathrm{CHB})$ patients. These patients were pretreated with directly acting antiviral therapy (entecavir) for 12 weeks with subsequent addition of peg-IFN $\lambda$ for up to 32 weeks. In a subgroup of patients, the addition of peg-IFN $\lambda$ provoked high serum levels of antiviral cytokine IL-18. We also observed the enhancement of natural killer cell polyfunctionality and the recovery of a pan-genotypic HBV-specific $\mathrm{CD}^{+} \mathrm{T}$ cells producing IFN- $\gamma$ with maintenance of HBV-specific CD8 ${ }^{+} \mathrm{T}$ cell antiviral and cytotoxic activities. It was only in these patients that we observed strong virological control with reductions in both viral replication and HBV antigen levels. Here, we show for the first time that in vivo peg-IFN $\lambda$ displays significant immunostimulatory properties with improvements in the main effectors mediating anti-HBV immunity. Interestingly, the maintenance in $\mathrm{HBV}$-specific CD8 ${ }^{+} \mathrm{T}$ cells in the presence of peg-IFN $\lambda$ is in contrast to previous studies showing that peg-IFN $\alpha$ treatment for $\mathrm{CHB}$ results in a detrimental effect on the functionality of this important antiviral $\mathrm{T}$ cell compartment.

Clinical Trial Registration: ClinicalTrials.gov NCT01204762.

Keywords: peg-interferon lambda, direct antiviral, hepatitis B, immunity, in vivo 


\section{INTRODUCTION}

Type I and type III interferons are the primary mediators of antiviral protection and the main therapeutic protagonists include IFN-alpha (IFN- $\alpha$ ) and IFN-lambda (IFN $\lambda$; IL-29), respectively. The immune-mediating properties of IFN- $\alpha$ have been extensively described both in vivo and in vitro in the context of many diseases $(1-5)$. However, little is understood about the immunomodulatory properties of IFN $\lambda$ in different disease states.

Both type I and III interferons have been shown to play an important role in control of HBV replication (6). Indeed, IFN$\alpha$ has been used as a treatment strategy for chronic hepatitis B (CHB) for over 40 years; however, its efficacy is suboptimal with resolution of infection being achieved in $<7 \%$ patients $(7,8)$. This is marginally improved during combination treatment with potent directly acting antiviral agents, such as entecavir (ETV) or tenofovir, but still remains inadequate with functional cure being achieved in only $15 \%$ of patients (9-11). The root cause of this may be immunological in nature. IFN- $\alpha$ has a dual mechanism of action in CHB, first, a direct antiviral effect achieved through inhibiting the synthesis of viral DNA, virus particles, and activation of antiviral enzymes, and second, an augmentation of antiviral host immunity (8). In CHB, IFN- $\alpha$ treatment induces narrowly focused immune responses restricted to activation of the innate immunity with little impact on reactivating stagnant HBV-specific adaptive immune responses which are central to long-term control of infection (12-15).

The precise role and activity of IFN $\lambda$ as an immunomodulator is unknown in vivo in humans and remains unclear in in vitro experiments. Indeed, the immune potentiating functions of IFN $\lambda$ are slowly starting to emerge (16-20). Early data suggests that although IFN $\lambda$ activates the same signaling pathway as IFN- $\alpha$, their temporal activation of ISGs as well as the induction of an antiviral response is different $(6,21,22)$. There is also some discrepancy regarding the direct impact of IFN $\lambda$ on immunocytes. Some studies find little or no expression of IFN $\lambda \mathrm{R}$ on immune cells, while others show IFN $\lambda$ R expression on both natural killer (NK) and T cells $(16,18,19,23,24)$. Further to this, IFN $\lambda$ is also reported to be unable to directly activate NK cell function, influence $\mathrm{T}$ cell differentiation, or induce cytokine production by T cells (25-27). In other studies, however, IFN $\lambda$ stimulates a significant antitumor immunity in murine models (28) and directly modulates $\mathrm{T}$ cell activity with promotion of Th1 and inhibition of Th2 responses $(16,29,30)$. These discrepancies are likely to be due to differences in the cellular, tissue, and animal models utilized and are compounded by a paucity of studies investigating the relationship between IFN $\lambda$ and the host immune response in vivo $(17,18$, $25,27)$. Defining whether IFN $\lambda$ acts as a broad or narrow immunostimulant in vivo in the context of a chronic disease will allow its appropriate therapeutic application in infection and disease.

In this study, we have comprehensively analyzed the impact of IFN $\lambda$ treatment on antiviral immunity in CHB patients. This is an ideal model infection to study the immunostimulatory effects of a therapeutic agent, as persistence of this virus is fundamentally associated with a weak antiviral immune response, characterized by defective NK cells and impaired virus-specific $T$ cell responses (31-38). Moreover, there is strong evidence demonstrating that the development and re-establishment of innate and adaptive host immunity in $\mathrm{CHB}$ is associated with control of infection (39-43). Therefore, using CHB infection as a model, we have for the first time utilized the structured platform of a clinical trial to dissect the relationship between the innate and adaptive host immune response and IFN $\lambda$.

\section{MATERIALS AND METHODS}

\section{Study Design and Patients}

We performed longitudinal immuno-surveillance of a subgroup of patients participating in a phase $2 \mathrm{~b}$ clinical study to evaluate the safety, efficacy and tolerability of pegylated IFN $\lambda$ (PegIFN $\lambda$ ) in combination with ETV in Hepatitis B e Antigen positive $\left(\mathrm{HBeAg}^{+}\right) \mathrm{CHB}$ patients [sponsored by Bristol-Myers Squibb, Wallingford (BMS), CT, USA]. Treatment naïve, $\mathrm{HBeAg}^{+} \mathrm{CHB}$ patients were recruited in 12 centers world-wide (Portland, California, Frankfurt, Hamburg, Hannover, Rotterdam, Taipei, Tainan, Seoul, and Taichung). The 13 patients (patient characteristics described in Table 1) received 12 weeks of ETV monotherapy $(0.5 \mathrm{mg} /$ day $)$ followed by up to 32 weeks of combination therapy ETV (0.5 mg/day)/PegIFN $\lambda$ (180 $\mu$ g/weekly) (Figure 1). Clinical parameters [HBV-DNA, HBeAg, hepatitis surface antigen (HBsAg), and alanine aminotransferase (ALT)] were measured in the serum at central laboratories. This study was approved by the Ethics Committee at each recruitment site and informed consent was obtained from all patients before enrollment. The isolation and cryopreservation of peripheral blood mononuclear cells (PBMC) was standardized by supplying each site with a written and video protocol. Prior to patient enrollment, each site performed PBMC isolation dry run which were shipped to the Institute of Hepatology for testing and once PBMCs met

\section{TABLE 1 | Patients characteristics at baseline.}

\begin{tabular}{lc}
\hline Characteristics & Entecavir and IFN- $\lambda$ \\
\hline Age (years) & $31.2(21,41)$ \\
Gender (male/female ratio) & $10: 3$ \\
Racial group (no. of patients) & \\
White & 1 \\
Asian* & 12 \\
Asian Indian & 1 \\
Chinese & 4 \\
Korean & 4 \\
Other & 3 \\
Alanine aminotransferase (IU/ml) & $88.2(38,297)$ \\
HBV-DNA (Log 10 copies/mll) & $8.3(6.4,9.7)$ \\
HBV genotype (no. of patients) & \\
B & 7 \\
C & 5 \\
D & 1 \\
qHBeAg (Log 10 copies/mll) & 1 \\
qHBsAg (Log copies/mlla & $2.4(0.1,2.8)$ \\
IL-28B (no. of patients) & $4.6(3.9,5.4)$ \\
CC & \\
CT & 9 \\
Non-cirrhotic & 4 \\
\hline
\end{tabular}

aThe data are shown as mean (range). "Asian subgroups are detailed below. 


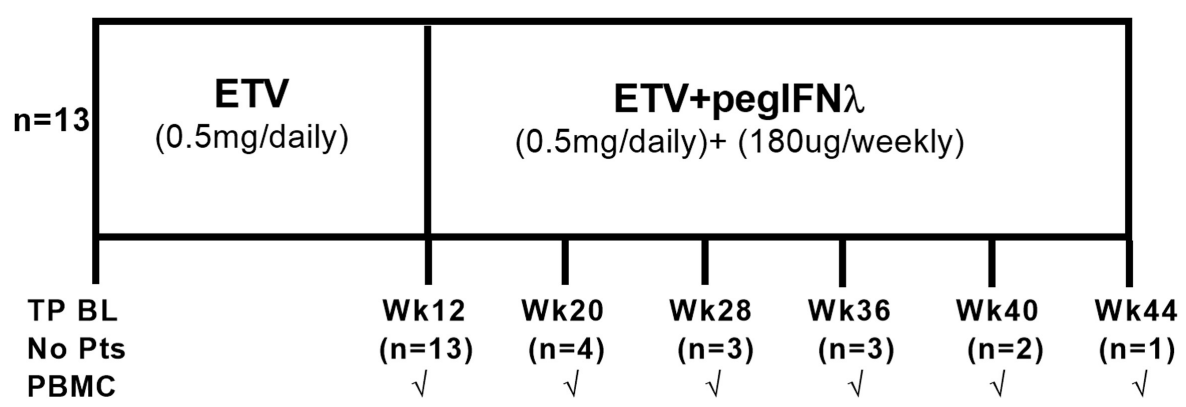

FIGURE 1 | Study design. All 13 patients were treated with entecavir (ETV) for 12 weeks and subsequently received ETV + peglFN- $\lambda$. The weeks of treatment reached by the patients are shown. Peripheral blood mononuclear cells (PBMC) collection are also indicated.

standardized criteria of $>95 \%$ viability and $>80 \%$ recovery did the sites initiate recruitment and collection of PBMC locally.

\section{PBMC Isolation}

Peripheral blood mononuclear cells were isolated from heparinized blood by lymphoprep gradient centrifugation as described previously $(33,34,37)$. The cryopreserved PBMC were stored at $-80^{\circ} \mathrm{C}$ at each site and subsequently batch shipped to the Institute of Hepatology for immunological analysis.

\section{Antigens}

Commercially available recombinant $\mathrm{HBV}$ nucleocapsid protein (HBcAg) and purified HBsAg were purchased from American Research products, Belmont, MA. HBV genotype A, B, C, and D 15-mers overlapping peptides covering the entire $\mathrm{HBcAg}$ and HBsAg region (Proimmune, Oxford, UK) were mixed in pools of five adjacent peptides. The pools were reconstituted at $8 \mathrm{mg} / \mathrm{ml}$ in dimethyl sulfoxide (DMSO). Recall antigen, tuberculin purified protein derivate (PPD) (Statens Seruminstitut, Copenhagen, Denmark), PMA, inomycin, and phytohemagglutinin (PHA) (Sigma, Poole, UK) were used as positive controls.

\section{Flow Cytometry}

All antibodies used for flow cytometry were purchased from BD Biosciences except when mentioned differently. Cells were acquired after staining on FACSCanto II flow cytometer (BD) and analyzed using FACS DIVA software.

\section{NK Analysis}

Peripheral blood mononuclear cells were surface stained with CD3-BV510, CD16-FITC, CD56-V450, NKG2D-PerCPeFluor710 (eBioscience), and TRAIL-PE (R\&D systems) as previously described $(44,45)$. To measure the frequency of IFN- $\gamma$-producing NK cells and NK cell degranulation, PBMC were incubated for $6 \mathrm{~h}$ with rhIL-12 and rhIL-18 (R\&D systems) and CFSE-stained K562 (E:T 5:1), respectively. CD107a-APC was added $2 \mathrm{~h}$ after the start of the culture to the PBMC: K562 cultures. A protein inhibitor cocktail (eBioscience) was added to all cultures $3 \mathrm{~h}$ from the start of the culture. PBMC were then surface stained as described above with CD3, CD16, and CD56 antibodies. The rhIL-12- and rhIL-18-stimulated wells were stained intracellularly with IFN- $\gamma$-PE-Cy7 as previously described $(44,45)$. PBMC were also stimulated with PMA/ionomycin as a positive control. The gating strategy to assess the ex vivo frequency of cytokine-producing $\left(\mathrm{CD} 56^{\text {bright }}, \mathrm{CD}^{-} 6^{-}\right)$and cytotoxic $\left(\mathrm{CD} 56^{\mathrm{dim}}, \mathrm{CD} 16^{+}\right) \mathrm{NK}$ subsets is described in Figure S1 in Supplementary Material.

\section{Frequency of HBV-Specific Producing T Cells IFN- $\gamma$}

The frequency was assessed by ELISpot assays. PBMC from patients and from a quality control PBMC batch (interassay control) were thawed, washed, and resuspended in RPMI1640/10\% AB serum. The cell viability was assessed with propidium iodide using an automated cell counter. ELISPOT assays were performed as previously described (34). PBMC were incubated in the presence of $\mathrm{HBcAg}(1 \mu \mathrm{g} / \mathrm{ml}), \mathrm{HBsAg}$ $(2 \mu \mathrm{g} / \mathrm{ml})$, peptide pools $(4 \mu \mathrm{g} / \mathrm{ml})$, PPD $(10 \mu \mathrm{g} / \mathrm{ml})$, and PHA $(2 \mu \mathrm{g} / \mathrm{ml})$.

\section{Functions of HBV-Specific T Cells}

Peripheral blood mononuclear cells were stimulated with HBV antigens and genotype-specific peptide pools for 7 days. On day 6, PBMC were subjected to a second round of stimulation with the HBV antigens and the overlapping HBV peptides and stained overnight with CD107a-APC and protein inhibitor cocktail. On day 7, PBMC were surface stained with CD3-BV510, CD4-V450, and CD8-APC-eFluor780 antibodies and stained intracellularly for IFN- $\gamma$ as described above. $\mathrm{PBMC}$ stimulated with PMA/ionomycin were used as a positive control.

For T-regulatory cell staining, PBMC were surface stained with CD3, CD4, and CD25-FITC, fixed and permeabilized with FoxP3 buffer (eBioscience) and stained intracellularly with FoxP3PerCPCy5.5 antibody as per the manufacturer's instructions.

\section{Determination of Serum Cytokine Profiles}

The serum levels of IL-2, IL-6, IL-8, IL-10, IL-12p70, IL-18, IP-10, IFN- $\gamma$, TNF- $\alpha$, Granzyme B, and MIP- $1 \alpha$ were quantitated using cytometric bead array (BD Biosciences) in accordance with manufacturer's instructions. The levels of IL-15, IL-17, IFN- $\alpha$, and IFN- $\beta$ were determined by ELISA (R\&D systems). 
Statistics Analysis

Statistical significance was assessed during course of the treatment before and after segregation of patients into groups using repeated measure one-way ANOVA and two-way ANOVA, respectively. Multiple comparisons tests were performed only when the null hypothesis was rejected with the ANOVA test. Pearson's correlation was used for correlation analyses. Analyses were conducted with the GraphPad Prism software version 6.05 for Windows (La Jolla, CA, USA). $p<0.05$ was considered statistically significant.

\section{RESULTS}

\section{Clinical Responses and Group Stratification}

This clinical study was terminated early for commercial reasons based on results from a parallel trial showing that non-inferiority of IFN $\lambda$ to IFN $\alpha$ was not met at week 24 . This early curtailment was not related to any safety concerns (46). The 13 patients initially received the full 12 weeks of ETV alone. Due to the truncated nature of this study, four patients received ETV plus Peg-IFN $\lambda$ for 8 weeks, three for 16 weeks, three for 24 weeks, two for 28 weeks, and one for 32 weeks. Patients' responses were not significantly different between consecutive time points and were therefore grouped during ETV and ETV plus Peg-IFN $\lambda$ treatments.

Treatment with ETV alone led to a mean drop of -3.72 $\log _{10}$ copies/ml in HBV-DNA levels during the first 12 weeks of therapy (Table 2 ) in line with previous studies $(47,48)$. A further reduction in viral replication was observed with the addition of Peg-IFN入 (-1.8 $\log _{10}$ copies/ml) (Table 2). A significant drop in HBsAg levels $\left(-0.63 \log _{10} \mathrm{IU} / \mathrm{ml}\right)$ and in the $\%$ HBsAg decline (ETV: $7.8 \%$ vs ETV + Peg-IFN $\lambda$ : $13.2 \%$ ) was also greater when Peg-IFN $\lambda$ was administered. HBeAg levels did not fall during ETV alone but the addition of Peg-IFN $\lambda$ did induce a significant reduction $\left(-0.73 \log _{10} \mathrm{IU} / \mathrm{ml}\right)$ and a drop in the $\% \mathrm{HBeAg}$ decline $($ ETV + Peg-IFN $\lambda$ : 31.5\%) (Table 2). No HBsAg or HBeAg loss or seroconversion occurred during the course of this truncated study, and no significant changes overall were observed in serum ALT (Table 2). Two patients experienced an ALT flare (ALT greater than $2 \times$ baseline and $5 \times$ the upper limit of normal) during add-on Peg-IFN $\lambda$.

Analysis of the clinical data revealed two distinct groups of patients based on the rates of decline of the viral antigen levels (HBeAg and HBsAg) when Peg-IFN $\lambda$ was introduced. Nine patients (Group 1) had a greater and significant reduction in $\mathrm{HBsAg}$ and HBeAg compared to the remaining four patients (Group 2) who showed no change in viral antigen levels during the addition of Peg-IFN $\lambda$ (Table 3). In Group 1, HBsAg and HBeAg declined by -0.73 and $-0.95 \log _{10} \mathrm{IU} / \mathrm{ml}$, respectively (Table 3 ). Furthermore, the difference in HBsAg and HBeAg levels between Group 1 and Group 2 was greater than $1 \log$ (Group 1 - Group 2: HBsAg: -1.07 $\log _{10}$; HBeAg: -1.08 $\log _{10}$ ) (Table 3).

Reductions in viremia were also different between these two groups. Significant reductions were observed in Group 1 between ETV alone and ETV plus Peg-IFN $\lambda\left(-3.84 \log _{10} ;-1.9 \log _{10}\right.$, respectively), whereas HBV-DNA decline was less pronounced in Group 2 (ETV alone: $-3.45 \log _{10}$; ETV + Peg-IFN $\lambda$ : $\left.-1.57 \log _{10}\right)$.

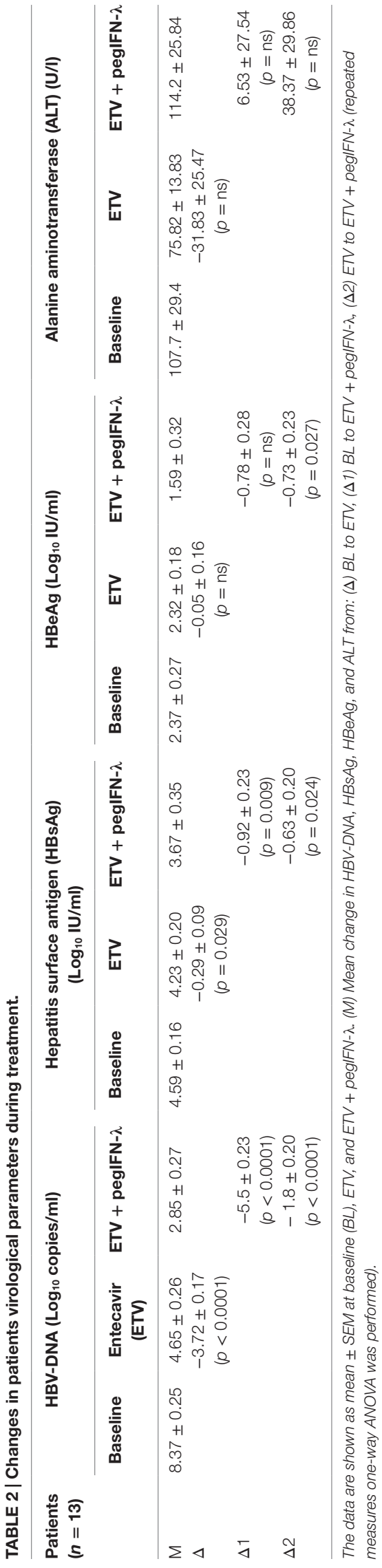

Frontiers in Immunology | www.frontiersin.org 
TABLE 3 | Changes in patients' virological parameters after segregation in two groups during treatment.

HBV-DNA ( $\log _{10}$ copies/ml) Hepatitis surface antigen $(\mathrm{HBsAg})$ $\left(\log _{10} \mathrm{IU} / \mathrm{ml}\right)$

Baseline

Enteca

$\mathrm{ETV}+$ pegIFN-

Baseline

ETV

ETV + pegIFN $-\lambda$

Baseline

$\mathrm{HBeAg}\left(\log _{10} \mathrm{IU} / \mathrm{ml}\right)$

Alanine aminotransferase (ALT) (U/I)

\begin{tabular}{|c|c|c|c|c|c|c|c|c|c|c|c|c|c|}
\hline \multirow{3}{*}{$\begin{array}{l}\text { Patient } \\
\text { Group } \\
1 \\
(n=9)\end{array}$} & $\begin{array}{l}\mathrm{M} \\
\Delta\end{array}$ & $8.14 \pm 0.30$ & $\begin{array}{c}4.30 \pm 0.30 \\
-3.84 \pm 0.17 \\
(p<0.0001)\end{array}$ & $2.40 \pm 0.26$ & $4.39 \pm 0.17$ & $\begin{array}{c}4.08 \pm 0.19 \\
-0.31 \pm 0.10 \\
(p=n s)\end{array}$ & $3.35 \pm 0.35$ & $2.21 \pm 0.37$ & $\begin{array}{c}2.19 \pm 0.24 \\
-0.013 \pm 0.22 \\
(p=n s)\end{array}$ & $1.23 \pm 0.37$ & $118.5 \pm 41.35$ & $\begin{array}{c}70 \pm 10.85 \\
-48.53 \pm 35.47 \\
(p=n s)\end{array}$ & $112.5 \pm 30.87$ \\
\hline & $\Delta 1$ & & & $\begin{array}{c}-5.74 \pm 0.24 \\
(p<0.0001)\end{array}$ & & & $\begin{array}{c}-1.04 \pm 0.32 \\
(p=0.005)\end{array}$ & & & $\begin{array}{c}-0.97 \pm 0.38 \\
(p=0.019)\end{array}$ & & & $\begin{array}{c}-6.07 \pm 26.02 \\
(p=n s)\end{array}$ \\
\hline & $\Delta 2$ & & & $\begin{array}{l}-1.9 \pm 0.23 \\
(p=0.0002)\end{array}$ & & & $\begin{array}{c}-0.73 \pm 0.28 \\
(p=0.042)\end{array}$ & & & $\begin{array}{c}-0.95 \pm 0.28 \\
(p=0.020)\end{array}$ & & & $\begin{array}{c}40.47 \pm 27.41 \\
(p=n s)\end{array}$ \\
\hline \multirow{3}{*}{$\begin{array}{l}\text { Patient } \\
\text { Group } \\
2 \\
(n=4)\end{array}$} & $\begin{array}{l}\mathrm{M} \\
\Delta\end{array}$ & $8.88 \pm 0.34$ & $\begin{array}{c}5.43 \pm 0.21 \\
-3.45 \pm 0.41 \\
(p<0.0001)\end{array}$ & $3.86 \pm 0.21$ & $5.05 \pm 0.18$ & $\begin{array}{c}4.81 \pm 0.40 \\
-0.24 \pm 0.23 \\
(p=n s)\end{array}$ & $4.42 \pm 0.28$ & $2.75 \pm 0.00$ & $\begin{array}{c}2.65 \pm 0.10 \\
-0.10 \pm 0.10 \\
(p=n s)\end{array}$ & $2.31 \pm 0.32$ & $82.75 \pm 26.09$ & $\begin{array}{c}88.25 \pm 41.49 \\
5.5 \pm 16.03 \\
(p=n s)\end{array}$ & $117.8 \pm 54.54$ \\
\hline & $\Delta 1$ & & & $\begin{array}{c}-5.02 \pm 0.46 \\
(p<0.0001)\end{array}$ & & & $\begin{array}{c}-0.63 \pm 0.11 \\
(p=n s)\end{array}$ & & & $\begin{array}{c}-0.44 \pm 0.16 \\
(p=n s)\end{array}$ & & & $\begin{array}{c}35.03 \pm 73.78 \\
(p=n s)\end{array}$ \\
\hline & $\Delta 2$ & & & $\begin{array}{c}-1.57 \pm 0.40 \\
\quad(p=n s)\end{array}$ & & & $\begin{array}{c}-0.39 \pm 0.13 \\
(p=n s)\end{array}$ & & & $\begin{array}{c}-0.33 \pm 0.16 \\
(p=n s)\end{array}$ & & & $\begin{array}{c}29.53 \pm 84.19 \\
(p=n s)\end{array}$ \\
\hline $\begin{array}{l}\text { M } \\
\text { Group } \\
1-M \\
\text { Group } \\
2\end{array}$ & $\Delta 3$ & $\begin{array}{c}-0.74 \pm 0.47 \\
(p=n s)\end{array}$ & $\begin{array}{c}-1.13 \pm 0.47 \\
(p=0.023)\end{array}$ & $\begin{array}{c}-1.46 \pm 0.47 \\
(p=0.041)\end{array}$ & $\begin{array}{c}-0.65 \pm 0.44 \\
(p=n s)\end{array}$ & $\begin{array}{c}-0.73 \pm 0.44 \\
(p=n s)\end{array}$ & $\begin{array}{c}-1.07 \pm 0.44 \\
(p=0.022)\end{array}$ & $\begin{array}{c}-0.54 \pm 0.46 \\
(p=n s)\end{array}$ & $\begin{array}{c}-0.45 \pm 0.46 \\
(p=n s)\end{array}$ & $\begin{array}{c}-1.08 \pm 0.46 \\
(p=0.026)\end{array}$ & $\begin{array}{c}35.77 \pm 47.83 \\
(p=n s)\end{array}$ & $\begin{array}{c}-18.26 \pm 47.83 \\
(p=n s)\end{array}$ & $\begin{array}{c}-7.21 \pm 47.83 \\
(p=n s)\end{array}$ \\
\hline
\end{tabular}

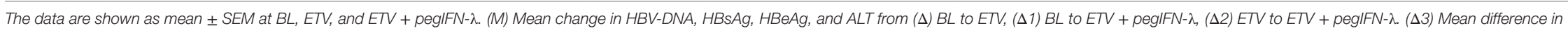
$H B V-D N A$ and viral antigens levels between group 1 and group 2 at BL, ETV, and ETV + pegIFN- $\lambda$. Repeated measures two-way ANOVA was performed. 
There was a difference in HBV-DNA levels greater than 1 Log between the two groups (ETV alone: $-1.13 \log _{10}$; ETV + PegIFN $\lambda$ : $\left.-1.46 \log _{10}\right)($ Table 3). Serum ALT levels were not different between Group 1 and 2.

As it has been previously shown that declining HBsAg levels denote activation of the host immunity and control of infection (49-52), the impact of IFN $\lambda$ on the host immunity was analyzed in the two groups identified: those who did (Group 1) or did not (Group 2) experience changes in antigen levels during combination treatment.

\section{Addition of Peg-IFN $\lambda$ Induces a Poly-Functional NK Response}

During $\mathrm{CHB}$, NK cells exhibit profound impairments in their ability to eliminate HBV by non-cytolytic and cytolytic mechanisms. They notably also lose the ability to orchestrate key players of the adaptive immune response $(36,53-55)$. Using standardized protocols (44), we analyzed the impact of Peg-IFN $\lambda$ on the phenotype and functionality of NK cells. In Group 1 patients (i.e., those with the greatest reduction in antigenaemia), we found an expansion in the frequency of these cells expressing the cytotoxic marker tumor necrosis factor-related apoptosis-inducing ligand (TRAIL) during combination Peg-IFNג (Figure 2A). Importantly, this pattern was not observed in Group 2 patients. We also assessed the relationships between the NK cell population and viral parameters and found the increase in TRAIL-positive NK cells to correlate positively with serum ALT levels in Group 1 patients $(r=0.848 ; p<0.0001)$. This was reflected in two patients who showed the greatest increase in these NK cells and had the greatest elevation in serum ALT, denoting a cytolytic clearance of infected hepatocytes during the Peg-IFN $\lambda$ phase of treatment. This observation was in line with previously described findings that in CHB, TRAIL expression increases together with ALT levels in patients treated with Peg-IFN $\alpha$ and denotes the elimination of infected hepatocytes (53). Interestingly, TRAIL-positive cytokine-producing NK cells of Group 1 patients were found to correlate negatively with HBsAg levels $(r=-0.699 ; p=0.0025)$.

The data also clearly demonstrate that NK functionality is modulated by the addition of Peg-IFN $\lambda$ in vivo and is different between the "responding" and "non-responding" groups. The cytotoxic potential of NK cells increased significantly in Group 1 but remained unchanged in Group 2 during the presence of PegIFN $\lambda$ (Figure 2B). The frequency of IFN- $\gamma$-producing NK cells also changed during treatment and increased with Peg-IFN $\lambda$ in Group 1, although the difference between ETV alone and ETV + Peg-IFN $\lambda$ was not statistically significant (Figure 2C). Nevertheless, the increase in the frequency of IFN- $\gamma$-producing NK cells was found to correlate negatively with $\mathrm{HBV}$ viral load $(r=-0.545 ; p=0.030)$. In contrast, the expression of the inhibitory marker, NKG2D did not change on any of the NK cells subsets during treatment (Figures 2D,E).

\section{Peg-IFN $\lambda$ Augments HBV-Specific T Cells Responses}

We comprehensively assessed the HBV-specific T cell response to recombinant $\mathrm{HBV}$ core, $\mathrm{HBV}$ surface antigen proteins, and overlapping genotype-specific core and surface peptides pools. Significant expansion was observed in the frequency of HBVspecific T cells producing IFN- $\gamma$ during the add-on Peg-IFN $\lambda$ phase of treatment in Group 1 but not in Group 2 (Figure 3A). We observed an increase in the percentage of patients who responded to $\mathrm{HBV}$ antigens and peptides pools initiated by treatment with ETV alone and this was augmented further when Peg-IFN $\lambda$ was added (Figure 3B). Further characterization of this reactive T cell population revealed that the increased virus-specific response observed in Group 1 was predominantly driven by the $\mathrm{CD}^{+}$ $\mathrm{T}$ cell population (Figure 3C). We also assessed the relationships between $\mathrm{CD}^{+} \mathrm{T}$ cell population and viral parameters and found this cell population to be negatively correlated with HBV-DNA $(r=-0.752 ; p=0.019)$ and HBsAg $(r=-0.795 ; p=0.010)$ and positively correlated with ALT $(r=0.824 ; p=0.006)$. A small but significant increase in the IFN- $\gamma$-producing $\mathrm{HBV}$-specific $\mathrm{CD}^{+}$ $\mathrm{T}$ cell population was also detected in $40 \%$ of patients in Group 1, during ETV and maintained during the addition of Peg-IFN $\lambda$ (Figure 3D). The change in this cell population was found to correlate negatively with HBsAg $(r=-0.676 ; p=0.045)$ and positively with serum ALT ( $r=0.770 ; p=0.015)$. We also evaluated the cytotoxic potential of $\mathrm{HBV}$-specific $\mathrm{CD}^{+} \mathrm{T}$ cells during the study by assessing their ability to degranulate and found that CD107a-positive HBV-specific $\mathrm{CD}^{+} \mathrm{T}$ cells were maintained through the treatment period, reflecting the steady levels of ALT observed in most of these patients (Figure 3E). There were, however, higher frequencies of this subset in Group 1 than Group 2. Indeed, during add-on PegIFN $\lambda$, 50\% of subjects in Group 1 had more than $10 \%$ of $\mathrm{HBV}$-specific CD8 ${ }^{+} \mathrm{T}$ cells expressing CD107a in contrast to none of the patients in Group 2. The frequency of T-regulatory cells was assessed and found to be low in all patients at baseline and did not change during treatment or between the groups (Figure 3F).

\section{Peg-IFN $\lambda$ Alters Serum IL-18 Levels}

Finally, we examined the impact of Peg-IFN $\lambda$ add-on on a panel of antiviral and pro/anti-inflammatory serum cytokines. Notably, we found that IL-18 levels significantly increased during treatment in Group 1 (Figure 4A). Although this increase is statistically significant, we recognize that it is quite small and the biological relevance needs to be further studied. This change in IL-18 was found to correlate positively with serum ALT $(r=0.432 ; p=0.024)$. The levels of IL- 8 , IL-15 IL-17, and IP-10 did not change during the course of treatment in the two groups (Figures 4B-E). Type I IFNs, IFN- $\beta$, and IFN- $\alpha$ could be detected but only in Group 1; however, their levels did not change during treatment (Figures $4 \mathbf{F}, \mathbf{G}$ ). The other cytokines measured, IL-2, IL-6, IL-10, IL-12p70, IFN- $\gamma$, TNF- $\alpha$, Granzyme B, and MIP- $1 \alpha$ were undetectable in both groups at all time points assessed.

\section{DISCUSSION}

The present data show for the first time that in vivo, IFN $\lambda$ displays immunostimulatory properties and provokes anti-HBV immunity in both the innate and adaptive compartments but only in patients that achieve the greatest decline in viral replication rates. This is of much relevance in $\mathrm{CHB}$, as reductions in, or loss of 

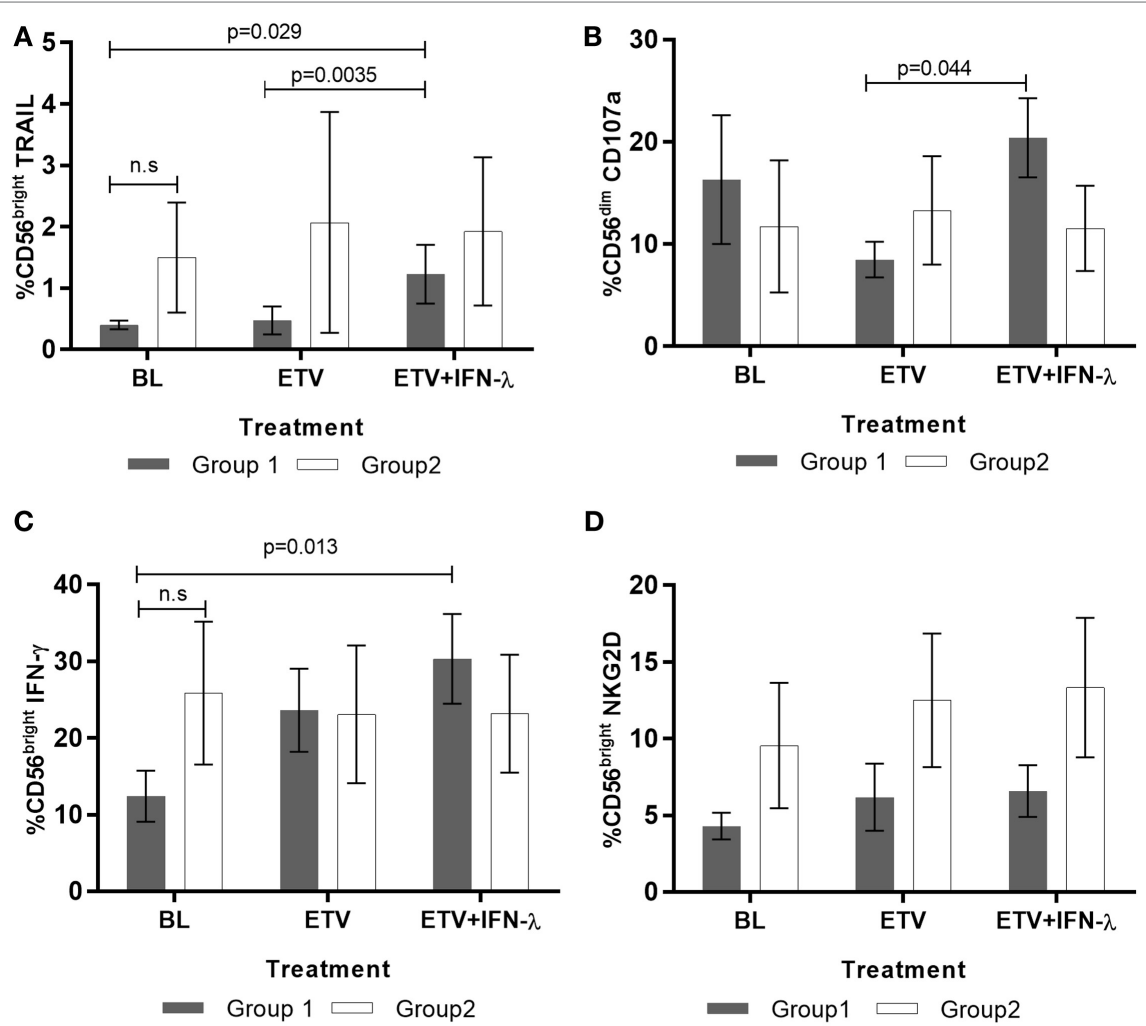

D
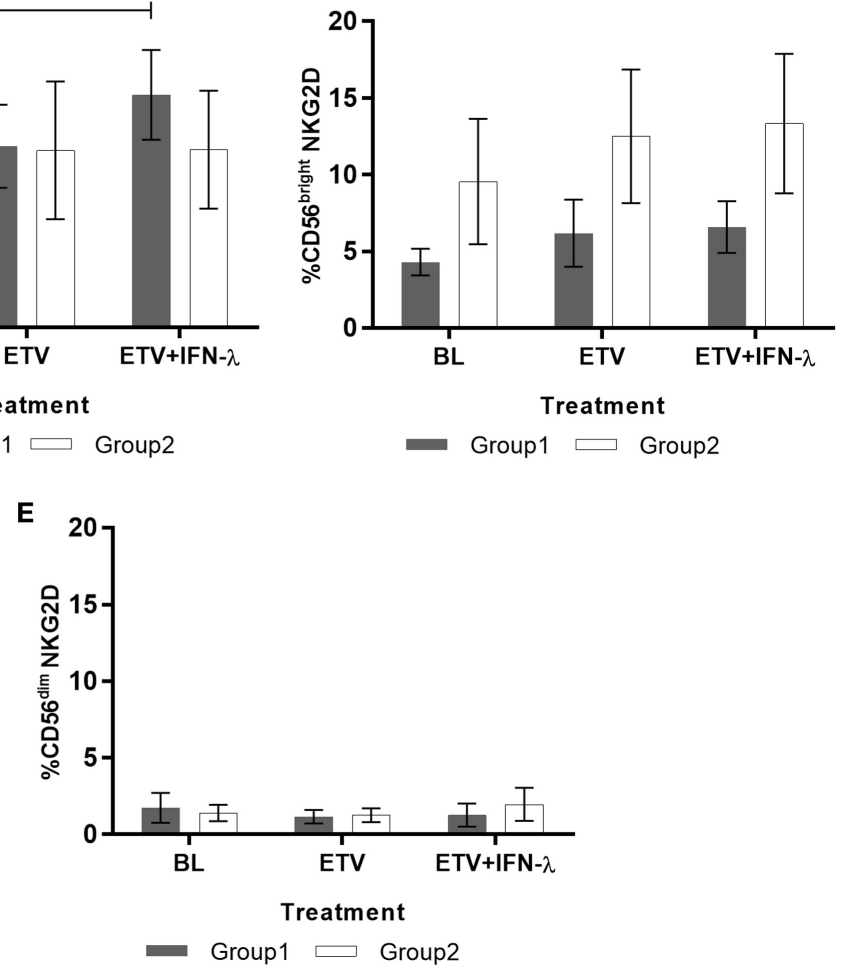

FIGURE 2 | Effect of treatment on natural killer (NK) cells response in Group $\mathbf{1}$ and Group 2 patients $(n=13)$. Percentage of (A) tumor necrosis factor-related apoptosis-inducing ligand (TRAIL)-positive CD56 bright NK cells (B) CD107a-producing cytotoxic CD56 dim NK cells, (C) IFN- $\gamma$ producing CD56 bright, (D) NKG2D-positive CD56 bright, and (E) NKG2D-positive CD56 ${ }^{\text {dim }}$ were measured by flow cytometry. A total of 100,000 events were collected during FACS acquisition and the subsequent analysis was performed using FACS DIVA software. Data are shown as mean \pm SEM. Two-way ANOVA followed by multiple comparison tests were performed for statistical analysis.

viremia in the serum does not equate to cure or viral eradication as the HBV genome persists as an integrated genome and/or as episomal covalently closed circular DNA for life (56). Long-term off-treatment control is only likely to be achieved via the activation strong antiviral host immunity, as seen in patients who resolve the infection spontaneously (56).

The findings from this study supports our previous reports demonstrating that overcoming immune hyporesponsiveness and development of immune-modulating therapies for $\mathrm{CHB}$ can only be achieved in patients who have low viral replication rates $(33,37)$. This observation is also supported by previous findings from Webster et al. showing that a HBV-DNA load less than $10^{7}$ copies $/ \mathrm{ml}$ is the threshold below which circulating multi-specific HBV-specific T cells can be consistently detected (57).

Natural killer cell and virus-specific T cell responses represent the main effectors of a favorable antiviral immune response and are critical in the long-term control of $\mathrm{HBV}$ infection $(58,59)$; functional impairments in their response to $\mathrm{HBV}$ have been widely shown to be correlated with an inability of the host to control replication and the persistence of infection $(37,38)$. In this study, we show that therapeutic administration of IFN $\lambda$ can induce a functional restoration of NK cells and virus-specific 

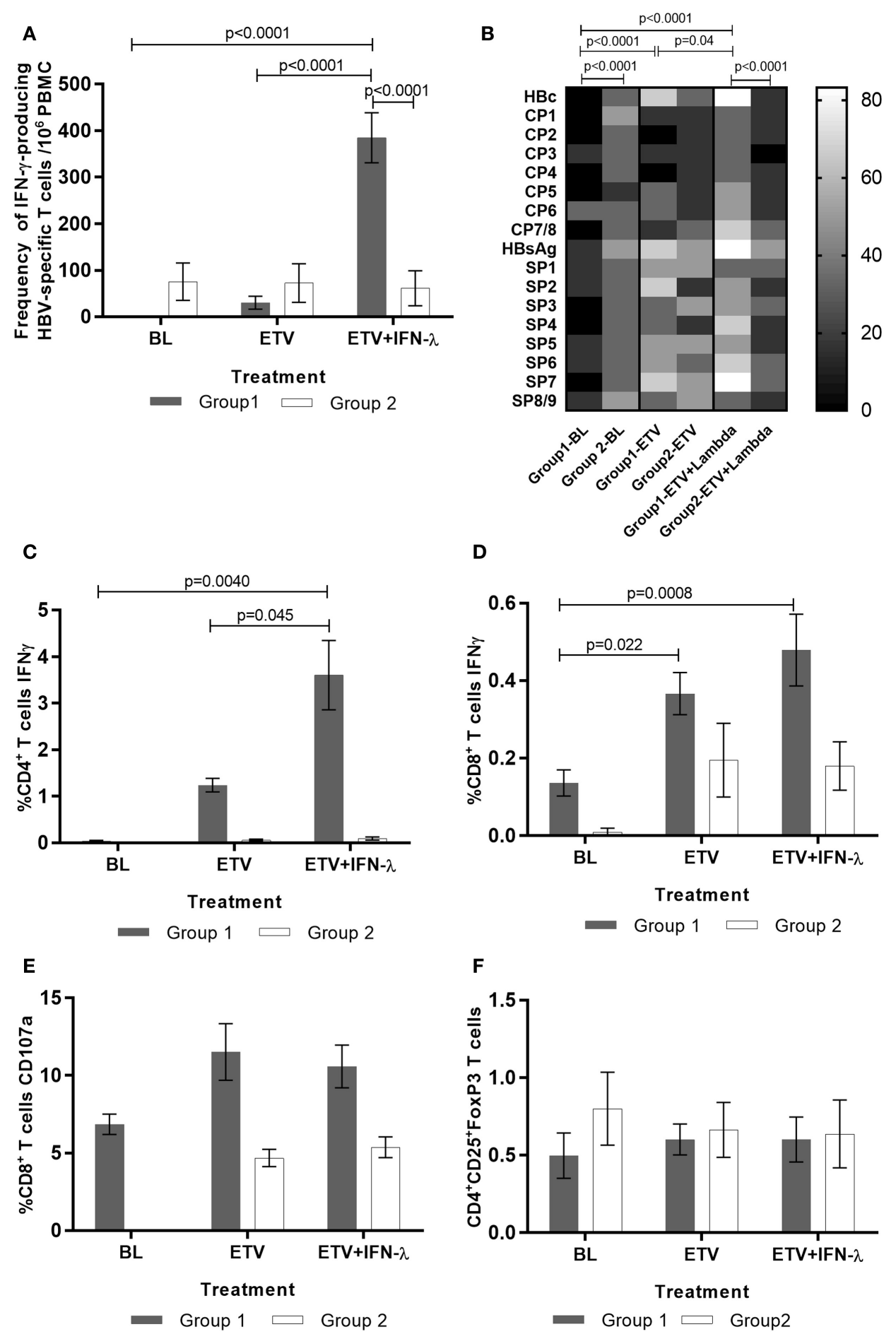

FIGURE 3 | Effect of treatment on HBV-specific T cells and T regs response in Group 1 and Group 2 patients $(n=13)$. The frequency of IFN- $\gamma$-producing HBV-specific T cells was evaluated by ELISPOT following peripheral blood mononuclear cells (PBMC) stimulation with HBV antigens and HBV-specific overlapping peptides. PBMC stimulation with recall antigen purified protein derivate and mitogen phytohemagglutinin elicited a measurable strong response which did not change significantly during the course of the treatment. (A) ELISPOT quantitation of frequency of IFN- $\gamma$-producing HBV-specific T cells. (B) Heat map representation of the percentage of patients reacting to each individual HBV antigen and peptide pool in ELISPOT. The assessment of the functionality of T cells was performed by FACS following two rounds of stimulation with HBV antigens and HBV-specific overlapping peptides covering HBV core and HBV surface regions. (C) IFN- $\gamma$ producing HBV-specific CD4+ T cells, (D) IFN- $\gamma$-producing HBV-specific CD8 ${ }^{+} \mathrm{T}$ cells, (E) CD107a-producing HBV-specific CD8 ${ }^{+} \mathrm{T}$ cells, and (F) T regulatory cells were quantitated by FACS. A total of 100,000 events were collected during FACS acquisition and the subsequent analysis was performed using FACS DIVA software. Data are shown as mean \pm SEM. Two-way ANOVA followed multiple comparison tests were performed for statistical analysis. 

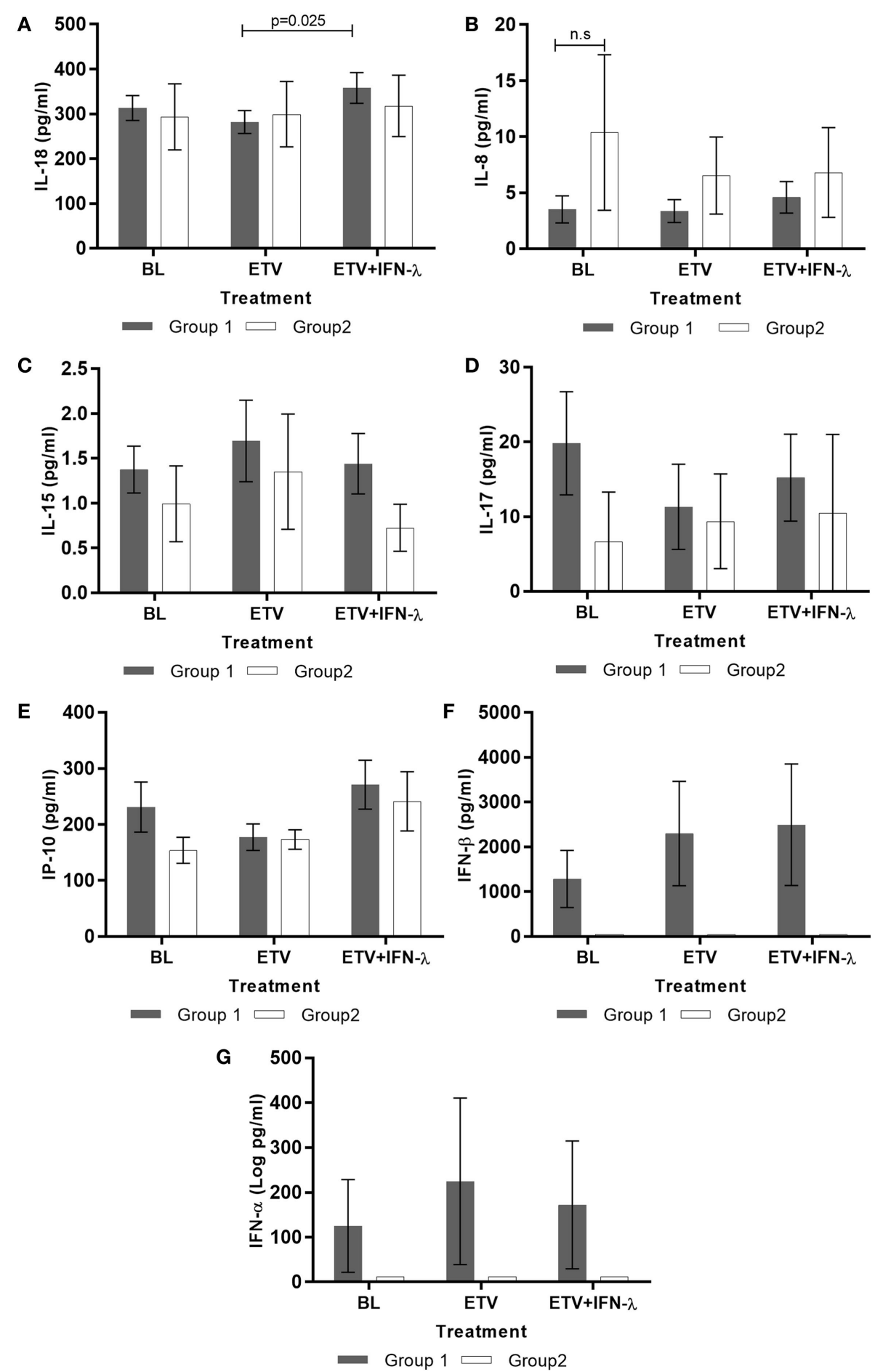

FIGURE 4 | Effect of treatment on serum cytokines production during treatment in patients group 1 and group 2 ( $n=13)$. Cytokines (A) IL-18, (B) IL-8, (C) IL15, (D) IL-17, (E) IP-10, (F) IFN- $\alpha$, and (G) IFN- $\beta$ were measured in the sera of patients by cytometric bead array or ELISA. Data are shown as mean \pm SEM. Two-way ANOVA followed by multiple comparison tests were performed for statistical analysis.

T cells antiviral abilities. Further to this, we show that the spectrum of changes observed with IFN $\lambda$ treatment are far wider than that observed with conventional IFN- $\alpha$ treatment in $\mathrm{CHB}$ patients.
Natural killer cells display two main effector functions that directly contribute to HBV infection control, direct killing of infected cells and the production of a variety of cytokines including the potent anti-HBV cytokine IFN- $\gamma$, which has directly 
antiviral activities and activates and promotes downstream antigen-specific adaptive immune responses (60). In our study, we find an improvement in these two functions of NK cells when Peg-IFN $\lambda$ is introduced and observe a notable increase of NK cells expressing TRAIL, an activation marker which induces target-cell apoptosis. Studies that investigated the modulation of NK cells during directly acting antiviral therapy have shown no effect on IFN- $\gamma$ producing CD56 ${ }^{\text {bright }}$ NK cells; which allow us to conclude that the increase in IFN- $\gamma$-producing NK cells observed during add-on Peg-IFN $\lambda$ is directly the result of IFN $\lambda$ administration $(36,61)$. IFN $\lambda$ mediated activation of cytolytic and non-cytolytic NK functionality is found in our study to be closely associated with reduction in viral replication rates and HBsAg levels. We therefore conclude that IFN $\lambda$ induces a significant expansion of both cytotoxic and IFN- $\gamma$-producing NK cells in patients with the greatest decline in viral replication during ETV.

In addition to the activation of NK cell functionality during IFN $\lambda$ therapy in Group 1 patients, we also observed significant restoration of the virus-specific $T$ cell responses which are widely known to be pivotal to the host control of HBV replication long-term $(43,62)$. We observed an increase in the frequency of $\mathrm{HBV}$-specific $\mathrm{CD}^{+}$and $\mathrm{CD}^{+} \mathrm{T}$ cells producing IFN- $\gamma$, which correlated strongly with the reduction of viremia and HBsAg. Further to this, we report an increase in the percentage of patients recognizing $\mathrm{HBV}$ antigens and peptide pools suggesting a diversification of epitope recognition and $\mathrm{T}$ cell activation. This is key for long-term control, as the ability of the immune system to attack multiple targets on a given pathogen has obvious advantages (63). Previous studies of ETV treatment of $\mathrm{HBeAg}$-positive patients have reported partial restoration of $\mathrm{HBV}$-specific $\mathrm{CD}^{+} \mathrm{T}$ cells and may explain the small increase in IFN- $\gamma$ producing $\mathrm{HBV}$-specific $\mathrm{CD}^{+} \mathrm{T}$ cells during ETV alone $(64,65)$. IFN- $\gamma$ producing HBV-specific $\mathrm{CD}^{+} \mathrm{T}$ cells, however, are not susceptible to this ETV-driven immune improvement. In parallel, during IFN $\lambda$ treatment, we observe a temporal relationship between $\mathrm{HBV}$-specific $\mathrm{CD} 8^{+} \mathrm{T}$ cells and mild elevations of liver transaminases denoting destruction of infected hepatocytes, suggesting the mobilization of activated cytotoxic immune cells into the liver. We have previously shown that this equilibrium between cytolytic and non-cytolytic $\mathrm{CD}^{+} \mathrm{T}$ cells functions is critical in control of infection without excessive exacerbation of inflammation and liver injury and this study reveals that IFN $\lambda$ favorably maintains this balance (66).

It was not possible to delineate the direct mechanisms by which IFN $\lambda$ activated NK and virus-specific T cell responses. We did explore whether this was mediated via the programmed death-1 pathway and found no modulation of the expression of this inhibitory pathway on NK or T cells ex vivo during the study period (data not shown). While further work will need to be performed to identify the specific pathways of IFN $\lambda$-mediated immune activation, our data does reveal a novel relationship between IFN $\lambda$ and IL-18, particularly in patients that showed greatest decline in HBsAg levels during IFN $\lambda$ treatment. This increase in IL-18 levels was however quite small and further studies are needed. The lack of changes in IFN- $\alpha$ and IFN- $\beta$ plasma levels during IFN $\lambda$ administration, is in line with previous in vitro work by Ank et al (67), suggests that this is also not the mechanism by which host antiviral immunity was induced.

The root cause for lack of immune reactivation in Group 2 could not be fully delineated due to the lack of sample availability. We had hypothesized that hyperexpression of the checkpoint inhibitor programmed death-1 may be partly responsible but this was not substantiated experimentally. This does not preclude the possibility of overexpression of other immune checkpoint inhibitors, on immune cells of group 2 patients, such as Tim-3 and CTLA- 4 which have been documented to impair immune function in CHB (68). Further to this, multiple reports have suggested that mutations and splice variants in the HBV genome and lower pregenomic/precore RNA could negatively influence the response to interferon treatment (69-71) and this may also be responsible for lack of response observed in Group 2. Finally and possibly most likely, IFN $\lambda$ intracellular signaling may have been disrupted by HBV-induced elevated levels of the suppressor of cytokine signaling SOCS 1 and 3 in Group 2 patients, thereby rendering IFN $\lambda$ treatment ineffective $(72,73)$. Further in-depth studies addressing these possibilities are required to characterize and confirm the mechanisms underlying IFN $\lambda$ nonresponsiveness in vivo.

In this study, we have highlighted several differences in the immunoregulatory activities of IFN $\lambda$ when compared to IFN- $\alpha$. The dysregulation of the adaptive immune response, a hallmark of $\mathrm{CHB}$, cannot be overcome by treatment with IFN- $\alpha$ (13). In fact, studies have shown that treatment with IFN- $\alpha$ actively results in the suppression of $\mathrm{HBV}$-specific $\mathrm{CD}^{+} \mathrm{T}$ cells $(12,14)$. It has been hypothesized that this is consequent to the known potent anti-proliferative effects of IFN- $\alpha$. This suppressive effect of IFN- $\alpha$ is not confined to $\mathrm{CHB}$ and has been demonstrated in several other chronic viral infections (74-77). We show that add-on IFN $\lambda$ treatment does not lead to the suppression but to the maintenance in the frequency of HBV-specific $\mathrm{CD}^{+} \mathrm{T}$ cells producing IFN $-\gamma$. Their negative strong correlation with $\mathrm{HBsAg}$ levels further highlights the importance of these cells in the control of HBV infection. In further contrast, IFN- $\alpha$ does not seem to activate the cytotoxic capacity of NK cells to kill target cells (13), whereas in this investigation we reveal the ability of IFN $\lambda$ to improve this important effector function. Our data also suggest that IFN $\lambda$ mediates improvement of anti-HBV immunity via IL-18. In contrast, IFN- $\alpha$ is believed to activate NK responses via IL-15 (13).

Anti-HBs seroconversion, the marker of functional cure in $\mathrm{CHB}$, was not seen in this study. It is well described that a decline of $>1$ Log HBsAg is predictive of sustained HBsAg loss in $\mathrm{HBeAg}$-positive $\mathrm{CHB}$ patients $(78,79)$ and we would suggest that given the steady decline of HBsAg levels seen in Group 1 patients during IFN $\lambda$ treatment, in concert with improvement in innate and adaptive immune responses in Group 1, we may have observed HBsAg loss, possibly followed by anti-HBs seroconversion post-treatment. Additionally, IFN $\lambda$ was only administered for a truncated 32 weeks and treatment for at least 48 weeks might be needed to observe an on-treatment HBsAg loss and anti-HBs seroconversion especially due to the restricted distribution of IFN $\lambda$ receptor. Regrettably, there was no posttreatment follow-up 
due to the early cessation of the clinical trial, due to commercial reasons based on results from a parallel trial showing that noninferiority of IFN $\lambda$ to IFN- $\alpha$ was not met at week 24 (46).

In conclusion, this study has demonstrated for the first time a dual immunomodulatory effect of IFN $\lambda$ on both the innate and adaptive arms of the immune response in vivo during chronic viral infection. When IFN $\lambda$ is administered in patients with suppressed HBV replication rates, it can induce broad immune stimulatory properties and drive activation of cytokine-producing and cytotoxic NK cells, IFN- $\gamma$-producing HBV-specific CD4 ${ }^{+} \mathrm{T}$ and maintenance of the antiviral and cytotoxic functions of $\mathrm{HBV}$ specific $\mathrm{CD}^{+} \mathrm{T}$ cells.

\section{ETHICS STATEMENT}

The study protocol was approved by the Institutional review board/Independent Ethics Committee at each recruitment site. An informed consent was obtained from all patients before enrolment at each site in accordance with the Declaration of Helsinki.

\section{AUTHOR CONTRIBUTIONS}

SP performed study design, performed experiments, analyzed results, and manuscript preparation. SM set up assays, conducted the immunological experiments, and acquired data. AR

\section{REFERENCES}

1. Levy DE, Garcia-Sastre A. The virus battles: IFN induction of the antiviral state and mechanisms of viral evasion. Cytokine Growth Factor Rev (2001) 12:143-56. doi:10.1016/S1359-6101(00)00027-7

2. Huber JP, Farrar JD. Regulation of effector and memory T-cell functions by type I interferon. Immunology (2011) 132:466-74. doi:10.1111/j.1365-2567. 2011.03412.x

3. Levy DE, Marie IJ, Durbin JE. Induction and function of type I and III interferon in response to viral infection. Curr Opin Virol (2011) 1:476-86. doi:10.1016/j.coviro.2011.11.001

4. Heim MH. Interferons and hepatitis C virus. Swiss Med Wkly (2012) 142:w13586. doi:10.4414/smw.2012.13586

5. Gibbert K, Schlaak JF, Yang D, Dittmer U. IFN-alpha subtypes: distinct biological activities in anti-viral therapy. Br J Pharmacol (2013) 168:1048-58. doi:10.1111/bph.12010

6. Pagliaccetti NE, Chu EN, Bolen CR, Kleinstein SH, Robek MD. Lambda and alpha interferons inhibit hepatitis B virus replication through a common molecular mechanism but with different in vivo activities. Virology (2010) 401:197-206. doi:10.1016/j.virol.2010.02.022

7. EASL. EASL clinical practice guidelines: management of chronic hepatitis B virus infection. J Hepatol (2012) 57:167-85. doi:10.1016/j.jhep.2012.02.010

8. Konerman MA, Lok AS. Interferon treatment for hepatitis B. Clin Liver Dis (2016) 20:645-65. doi:10.1016/j.cld.2016.06.002

9. Kittner JM, Sprinzl MF, Grambihler A, Weinmann A, Schattenberg JM, Galle PR, et al. Adding pegylated interferon to a current nucleos(t)ide therapy leads to HBsAg seroconversion in a subgroup of patients with chronic hepatitis B. J Clin Virol (2012) 54:93-5. doi:10.1016/j.jcv.2012.01.024

10. Boglione L, D’avolio A, Cariti G, Milia MG, Simiele M, De NA, et al. Sequential therapy with entecavir and PEG-INF in patients affected by chronic hepatitis B and high levels of HBV-DNA with non-D genotypes. J Viral Hepat (2013) 20:e11-9. doi:10.1111/jvh.12018

11. Ouzan D, Penaranda G, Joly H, Khiri H, Pironti A, Halfon P. Add-on peginterferon leads to loss of HBsAg in patients with HBeAg-negative chronic hepatitis and HBV DNA fully suppressed by long-term nucleotide analogs. J Clin Virol (2013) 58:713-7. doi:10.1016/j.jcv.2013.09.020 performed statistical analysis. HC performed experiments. SZ, CW, P-JC, C-YP, T-TC, SL, RG, M-SC, HW, MD, C-WK, MS, SP, KK, TH-L, and H-CC recruited patients, collected blood and serum samples, and isolated PBMC. MW-R and EC performed clinical and immunological trial design and manuscript preparation. RW funded the research and edited the manuscript. SC performed study design, analyzed results, and manuscript preparation.

\section{FUNDING}

This investigator initiated study was funded by Bristol-Myers Squibb and The Foundation for Liver Research.

\section{SUPPLEMENTARY MATERIAL}

The Supplementary Material for this article can be found online at http://journal.frontiersin.org/article/10.3389/fimmu.2017.00621/ full\#supplementary-material.

FIGURE S1 | Flow cytometry gating strategy for analysis of CD56 bright, CD56 ${ }^{\text {dim }}$ NK cells subsets. (A) The lymphocyte population was gated on forward and side scatter. (B) The NK cells population was identified with the CD56 and CD3 markers. (C) CD56 and CD16 markers were used to identify CD56 bright NK cells (CD56 bright/CD16-) and CD56 dim NK cells (CD56 dim/CD16+) subpopulations. A total of 250,000 events were acquired. Analysis was performed using FACS diva software.
12. Penna A, Laccabue D, Libri I, Giuberti T, Schivazappa S, Alfieri A, et al. Peginterferon-alpha does not improve early peripheral blood HBV-specific T-cell responses in HBeAg-negative chronic hepatitis. J Hepatol (2012) 56:1239-46. doi:10.1016/j.jhep.2011.12.032

13. Micco L, Peppa D, Loggi E, Schurich A, Jefferson L, Cursaro C, et al. Differential boosting of innate and adaptive antiviral responses during pegylated-interferon-alpha therapy of chronic hepatitis B. J Hepatol (2013) 58:225-33. doi:10.1016/j.jhep.2012.09.029

14. Tan AT, Hoang LT, Chin D, Rasmussen E, Lopatin U, Hart S, et al. Reduction of HBV replication prolongs the early immunological response to IFNalpha therapy. J Hepatol (2014) 60:54-61. doi:10.1016/j.jhep.2013.08.020

15. Stelma F, De NA, Tempelmans Plat-Sinnige MJ, Jansen L, Takkenberg RB, Reesink HW, et al. Natural killer cell characteristics in patients with chronic hepatitis B virus (HBV) infection are associated with HBV surface antigen clearance after combination treatment with pegylated interferon alfa-2a and adefovir. J Infect Dis (2015) 212:1042-51. doi:10.1093/infdis/jiv180

16. Dai J, Megjugorac NJ, Gallagher GE, Yu RY, Gallagher G. IFN-lambda1 (IL-29) inhibits GATA3 expression and suppresses Th2 responses in human naive and memory T cells. Blood (2009) 113:5829-38. doi:10.1182/ blood-2008-09-179507

17. Megjugorac NJ, Gallagher GE, Gallagher G. Modulation of human plasmacytoid DC function by IFN-lambda1 (IL-29). J Leukoc Biol (2009) 86:1359-63. doi:10.1189/jlb.0509347

18. Witte K, Gruetz G, Volk HD, Looman AC, Asadullah K, Sterry W, et al. Despite IFN-lambda receptor expression, blood immune cells, but not keratinocytes or melanocytes, have an impaired response to type III interferons: implications for therapeutic applications of these cytokines. Genes Immun (2009) 10:702-14. doi:10.1038/gene.2009.72

19. De Groen RA, Boltjes A, Hou J, Liu BS, Mcphee F, Friborg J, et al. IFN-lambdamediated IL-12 production in macrophages induces IFN-gamma production in human NK cells. Eur J Immunol (2015) 45(1):250-9. doi:10.1002/ eji.201444903

20. Kelly A, Robinson MW, Roche G, Biron CA, O’farrelly C, Ryan EJ. Immune cell profiling of IFN-lambda response shows pDCs express highest level of IFN-lambdaR1 and are directly responsive via the JAK-STAT pathway. J Interferon Cytokine Res (2016) 36:671-80. doi:10.1089/jir.2015.0169 
21. Doyle SE, Schreckhise H, Khuu-Duong K, Henderson K, Rosler R, Storey H, et al. Interleukin-29 uses a type 1 interferon-like program to promote antiviral responses in human hepatocytes. Hepatology (2006) 44:896-906. doi:10.1002/ hep. 21312

22. Marcello T, Grakoui A, Barba-Spaeth G, Machlin ES, Kotenko SV, Macdonald MR, et al. Interferons alpha and lambda inhibit hepatitis $C$ virus replication with distinct signal transduction and gene regulation kinetics. Gastroenterology (2006) 131:1887-98. doi:10.1053/j.gastro.2006.09.052

23. Sommereyns C, Paul S, Staeheli P, Michiels T. IFN-lambda (IFN-lambda) is expressed in a tissue-dependent fashion and primarily acts on epithelial cells in vivo. PLoS Pathog (2008) 4:e1000017. doi:10.1371/journal.ppat.1000017

24. Liu BS, Janssen HL, Boonstra A. IL-29 and IFNalpha differ in their ability to modulate IL-12 production by TLR-activated human macrophages and exhibit differential regulation of the IFNgamma receptor expression. Blood (2011) 117:2385-95. doi:10.1182/blood-2010-07-298976

25. Numasaki M, Tagawa M, Iwata F, Suzuki T, Nakamura A, Okada M, et al. IL-28 elicits antitumor responses against murine fibrosarcoma. J Immunol (2007) 178:5086-98. doi:10.4049/jimmunol.178.8.5086

26. Dring MM, Morrison MH, Mcsharry BP, Guinan KJ, Hagan R; Irish HCV Research Consortium, et al. Innate immune genes synergize to predict increased risk of chronic disease in hepatitis C virus infection. Proc Natl Acad Sci U S A (2011) 108:5736-41. doi:10.1073/pnas.1016358108

27. Morrison MH, Keane C, Quinn LM, Kelly A, O'farrelly C, Bergin C, et al. IFNL cytokines do not modulate human or murine NK cell functions. Hum Immunol (2014) 75:996-1000. doi:10.1016/j.humimm.2014.06.016

28. Sato A, Ohtsuki M, Hata M, Kobayashi E, Murakami T. Antitumor activity of IFN-lambda in murine tumor models. J Immunol (2006) 176:7686-94. doi:10.4049/jimmunol.176.12.7686

29. Jordan WJ, Eskdale J, Srinivas S, Pekarek V, Kelner D, Rodia M, et al. Human interferon lambda-1 (IFN-lambda1/IL-29) modulates the Th1/Th2 response. Genes Immun (2007) 8:254-61. doi:10.1038/sj.gene.6364348

30. Koltsida O, Hausding M, Stavropoulos A, Koch S, Tzelepis G, Ubel C, et al. IL-28A (IFN-lambda2) modulates lung DC function to promote Th1 immune skewing and suppress allergic airway disease. EMBO Mol Med (2011) 3:348-61. doi:10.1002/emmm.201100142

31. Boni C, Fisicaro P, Valdatta C, Amadei B, Di VP, Giuberti T, et al. Characterization of hepatitis B virus (HBV)-specific T-cell dysfunction in chronic HBV infection. J Virol (2007) 81:4215-25. doi:10.1128/JVI.02844-06

32. Lau GK, Cooksley H, Ribeiro RM, Powers KA, Shudo E, Bowden S, et al. Impact of early viral kinetics on T-cell reactivity during antiviral therapy in chronic hepatitis B. Antivir Ther (2007) 12:705-18.

33. Cooksley H, Chokshi S, Maayan Y, Wedemeyer H, Andreone P, Gilson R, et al. Hepatitis B virus e antigen loss during adefovir dipivoxil therapy is associated with enhanced virus-specific CD4+ T-cell reactivity. Antimicrob Agents Chemother (2008) 52:312-20. doi:10.1128/AAC.00467-07

34. Evans A, Riva A, Cooksley H, Phillips S, Puranik S, Nathwani A, et al. Programmed death 1 expression during antiviral treatment of chronic hepatitis B: impact of hepatitis B e-antigen seroconversion. Hepatology (2008) 48:759-69. doi:10.1002/hep.22419

35. Fisicaro P, Valdatta C, Massari M, Loggi E, Biasini E, Sacchelli L, et al. Antiviral intrahepatic T-cell responses can be restored by blocking programmed death-1 pathway in chronic hepatitis B. Gastroenterology (2010) 138:682-93, 693.e1-4. doi:10.1053/j.gastro.2009.09.052

36. Tjwa ET, Van Oord GW, Hegmans JP, Janssen HL, Woltman AM. Viral load reduction improves activation and function of natural killer cells in patients with chronic hepatitis B. J Hepatol (2011) 54:209-18. doi:10.1016/j. jhep.2010.07.009

37. Chokshi S, Cooksley H, Riva A, Phillips S, Williams R, Gaggar A, et al. Identification of serum cytokine profiles associated with HBeAg seroconversion following antiviral treatment interruption. Viral Immunol (2014) 27:235-44. doi:10.1089/vim.2014.0022

38. Rehermann B. Natural killer cells in viral hepatitis. Cell Mol Gastroenterol Hepatol (2015) 1:578-88. doi:10.1016/j.jcmgh.2015.09.004

39. Penna A, Artini M, Cavalli A, Levrero M, Bertoletti A, Pilli M, et al. Longlasting memory $\mathrm{T}$ cell responses following self-limited acute hepatitis B. J Clin Invest (1996) 98:1185-94. doi:10.1172/JCI118902

40. Lau GK, Liang R, Chiu EK, Lee CK, Lam SK. Hepatic events after bone marrow transplantation in patients with hepatitis B infection: a case controlled study. Bone Marrow Transplant (1997) 19:795-9. doi:10.1038/sj.bmt.1700744
41. Lau GK, Lok AS, Liang RH, Lai CL, Chiu EK, Lau YL, et al. Clearance of hepatitis B surface antigen after bone marrow transplantation: role of adoptive immunity transfer. Hepatology (1997) 25:1497-501. doi:10.1002/hep. 510250631

42. Lau GK, Liang R, Lee CK, Yuen ST, Hou J, Lim WL, et al. Clearance of persistent hepatitis $\mathrm{B}$ virus infection in Chinese bone marrow transplant recipients whose donors were anti-hepatitis B core- and anti-hepatitis B surface antibody-positive. J Infect Dis (1998) 178:1585-91. doi:10.1086/ 314497

43. Webster GJ, Reignat S, Maini MK, Whalley SA, Ogg GS, King A, et al. Incubation phase of acute hepatitis B in man: dynamic of cellular immune mechanisms. Hepatology (2000) 32:1117-24. doi:10.1053/jhep.2000.19324

44. Riva A, Laird M, Casrouge A, Ambrozaitis A, Williams R, Naoumov NV, et al. Truncated CXCL10 is associated with failure to achieve spontaneous clearance of acute hepatitis C infection. Hepatology (2014) 60(2):487-96. doi:10.1002/ hep. 27139

45. Markwick LJ, Riva A, Ryan JM, Cooksley H, Palma E, Tranah TH, et al. Blockade of PD1 and TIM3 restores innate and adaptive immunity in patients with acute alcoholic hepatitis. Gastroenterology (2015) 148:590-602. doi:10.1053/j.gastro.2014.11.041

46. Chan HL, Ahn SH, Chang TT, Peng CY, Wong D, Coffin CS, et al. Peginterferon lambda for the treatment of HBeAg-positive chronic hepatitis B: a randomized phase 2b study (LIRA-B). J Hepatol (2016) 64:1011-9. doi:10.1016/j. jhep.2015.12.018

47. Chang TT, Gish RG, De MR, Gadano A, Sollano J, Chao YC, et al. A comparison of entecavir and lamivudine for HBeAg-positive chronic hepatitis B. N Engl J Med (2006) 354:1001-10. doi:10.1056/NEJMoa051285

48. Leung N, Peng CY, Hann HW, Sollano J, Lao-Tan J, Hsu CW, et al. Early hepatitis B virus DNA reduction in hepatitis B e antigen-positive patients with chronic hepatitis $B$ : a randomized international study of entecavir versus adefovir. Hepatology (2009) 49:72-9. doi:10.1002/hep.22658

49. Lampertico P, Liaw YF. New perspectives in the therapy of chronic hepatitis B. Gut (2012) 61(Suppl 1):i18-24. doi:10.1136/gutjnl-2012-302085

50. Tseng TC, Kao JH. Clinical utility of quantitative HBsAg in natural history and nucleos $(\mathrm{t})$ ide analogue treatment of chronic hepatitis $\mathrm{B}$ : new trick of old dog. J Gastroenterol (2013) 48:13-21. doi:10.1007/s00535-012-0668-y

51. Honer $\mathrm{Zu} \mathrm{SC}$, Cornberg M. The role of HBsAg levels in the current management of chronic HBV infection. Ann Gastroenterol (2014) 27:105-12.

52. Van Campenhout MJ, Janssen HL. How to achieve immune control in chronic hepatitis B? Hepatol Int (2015) 9:9-16. doi:10.1007/s12072-014-9571-3

53. Dunn C, Brunetto M, Reynolds G, Christophides T, Kennedy PT, Lampertico P, et al. Cytokines induced during chronic hepatitis B virus infection promote a pathway for NK cell-mediated liver damage. J Exp Med (2007) 204:667-80. doi:10.1084/jem.20061287

54. Oliviero B, Varchetta S, Paudice E, Michelone G, Zaramella M, Mavilio D, et al. Natural killer cell functional dichotomy in chronic hepatitis B and chronic hepatitis C virus infections. Gastroenterology (2009) 137:1151-60, 1160.e1-7. doi:10.1053/j.gastro.2009.05.047

55. Sun C, Fu B, Gao Y, Liao X, Sun R, Tian Z, et al. TGF-betal down-regulation of NKG2D/DAP10 and 2B4/SAP expression on human NK cells contributes to HBV persistence. PLoS Pathog (2012) 8:e1002594. doi:10.1371/journal. ppat.1002594

56. Gish RG, Given BD, Lai CL, Locarnini SA, Lau JY, Lewis DL, et al. Chronic hepatitis B: virology, natural history, current management and a glimpse at future opportunities. Antiviral Res (2015) 121:47-58. doi:10.1016/j.antiviral. 2015.06.008

57. Webster GJ, Reignat S, Brown D, Ogg GS, Jones L, Seneviratne SL, et al. Longitudinal analysis of CD8+ T cells specific for structural and nonstructural hepatitis B virus proteins in patients with chronic hepatitis B: implications for immunotherapy. J Virol (2004) 78:5707-19. doi:10.1128/ JVI.78.11.5707-5719.2004

58. Perussia B. The cytokine profile of resting and activated NK cells. Methods (1996) 9:370-8. doi:10.1006/meth.1996.0042

59. Moretta A, Marcenaro E, Parolini S, Ferlazzo G, Moretta L. NK cells at the interface between innate and adaptive immunity. Cell Death Differ (2008) 15:226-33. doi:10.1038/sj.cdd.4402170

60. Strowig T, Brilot F, Munz C. Noncytotoxic functions of NK cells: direct pathogen restriction and assistance to adaptive immunity. J Immunol (2008) 180:7785-91. doi:10.4049/jimmunol.180.12.7785 
61. Peppa D, Micco L, Javaid A, Kennedy PT, Schurich A, Dunn C, et al. Blockade of immunosuppressive cytokines restores NK cell antiviral function in chronic hepatitis B virus infection. PLoS Pathog (2010) 6:e1001227. doi:10.1371/ journal.ppat.1001227

62. Maini MK, Boni C, Lee CK, Larrubia JR, Reignat S, Ogg GS, et al. The role of virus-specific CD8(+) cells in liver damage and viral control during persistent hepatitis B virus infection. J Exp Med (2000) 191:1269-80. doi:10.1084/ jem.191.8.1269

63. Vanderlugt CL, Miller SD. Epitope spreading in immune-mediated diseases: implications for immunotherapy. Nat Rev Immunol (2002) 2:85-95. doi:10.1038/nri724

64. You J, Sriplung H, Geater A, Chongsuvivatwong V, Zhuang L, Li YL, et al. Impact of viral replication inhibition by entecavir on peripheral $\mathrm{T}$ lymphocyte subpopulations in chronic hepatitis B patients. BMC Infect Dis (2008) 8:123. doi:10.1186/1471-2334-8-123

65. Boni C, Laccabue D, Lampertico P, Giuberti T, Vigano M, Schivazappa S, et al. Restored function of HBV-specific T cells after long-term effective therapy with nucleos(t)ide analogues. Gastroenterology (2012) 143:963-73. doi:10.1053/j.gastro.2012.07.014

66. Phillips S, Chokshi S, Riva A, Evans A, Williams R, Naoumov NV. CD8(+) $\mathrm{T}$ cell control of hepatitis B virus replication: direct comparison between cytolytic and noncytolytic functions. J Immunol (2010) 184:287-95. doi:10.4049/ jimmunol.0902761

67. Ank N, West H, Bartholdy C, Eriksson K, Thomsen AR, Paludan SR. Lambda interferon (IFN-lambda), a type III IFN, is induced by viruses and IFNs and displays potent antiviral activity against select virus infections in vivo. $J$ Virol (2006) 80:4501-9. doi:10.1128/JVI.80.9.4501-4509.2006

68. Ye B, Liu X, Li X, Kong H, Tian L, Chen Y. T-cell exhaustion in chronic hepatitis B infection: current knowledge and clinical significance. Cell Death Dis (2015) 6:e1694. doi:10.1038/cddis.2015.42

69. Lu J-J, Chen E-Q, Yang J-H, Zhou T-Y, Liu L, Tang H. A mutation in the interferon regulatory element of $\mathrm{HBV}$ may influence the response of interferon treatment in chronic hepatitis B patients. Virol J (2012) 9:10. doi:10.1186/ 1743-422X-9-10

70. Chen J, Wu M, Wang F, Zhang W, Wang W, Zhang X, et al. Hepatitis B virus spliced variants are associated with an impaired response to interferon therapy. Sci Rep (2015) 5:16459. doi:10.1038/srep16459

71. Wu HL, Hsiao TH, Chen PJ, Wong SH, Kao JH, Chen DS, et al. Liver gene expression profiles correlate with virus infection and response to interferon therapy in chronic hepatitis B patients. Sci Rep (2016) 6:31349. doi:10.1038/ srep31349

72. Du L-Y, Cui Y-L, Chen E-Q, Cheng X, Liu L, Tang H. Correlation between the suppressor of cytokine signaling-1 and 3 and hepatitis $\mathrm{B}$ virus: possible roles in the resistance to interferon treatment. Virol J (2014) 11:51. doi:10.1186/1743-422X-11-51

73. Wei H, Wang S, Chen Q, Chen Y, Chi X, Zhang L, et al. Suppression of interferon lambda signaling by SOCS-1 results in their excessive production during influenza virus infection. PLoS Pathog (2014) 10:e1003845. doi:10.1371/ journal.ppat.1003845

74. Barnes E, Gelderblom HC, Humphreys I, Semmo N, Reesink HW, Beld MG, et al. Cellular immune responses during high-dose interferon-alpha induction therapy for hepatitis C virus infection. J Infect Dis (2009) 199:819-28. doi:10.1086/597072

75. Marshall HD, Urban SL, Welsh RM. Virus-induced transient immune suppression and the inhibition of T cell proliferation by type I interferon. J Virol (2011) 85:5929-39. doi:10.1128/JVI.02516-10

76. O'Brien M, Manches O, Sabado RL, Baranda SJ, Wang Y, Marie I, et al. Spatiotemporal trafficking of HIV in human plasmacytoid dendritic cells defines a persistently IFN-alpha-producing and partially matured phenotype. J Clin Invest (2011) 121:1088-101. doi:10.1172/JCI44960

77. Pinto AK, Daffis S, Brien JD, Gainey MD, Yokoyama WM, Sheehan KC, et al. A temporal role of type I interferon signaling in CD8+ T cell maturation during acute West Nile virus infection. PLoS Pathog (2011) 7:e1002407. doi:10.1371/ journal.ppat.1002407

78. Brunetto MR, Moriconi F, Bonino F, Lau GK, Farci P, Yurdaydin C, et al. Hepatitis B virus surface antigen levels: a guide to sustained response to peginterferon alfa-2a in $\mathrm{HBeAg}$-negative chronic hepatitis B. Hepatology (2009) 49:1141-50. doi:10.1002/hep.22760

79. Chan HL, Wong VW, Wong GL, Tse CH, Chan HY, Sung JJ. A longitudinal study on the natural history of serum hepatitis B surface antigen changes in chronic hepatitis B. Hepatology (2010) 52:1232-41. doi:10.1002/hep. 23803

Conflict of Interest Statement: Megan Wind-Rotolo and Elizabeth Cooney are employed by Bristol-Myers Squibb. The other authors declare no conflict of interest.

Copyright (c) 2017 Phillips, Mistry, Riva, Cooksley, Hadzhiolova-Lebeau, Plavova, Katzarov, Simonova, Zeuzem, Woffendin, Chen, Peng, Chang, Lueth, De Knegt, Choi, Wedemeyer, Dao, Kim, Chu, Wind-Rotolo, Williams, Cooney and Chokshi. This is an open-access article distributed under the terms of the Creative Commons Attribution License (CC BY). The use, distribution or reproduction in other forums is permitted, provided the original author(s) or licensor are credited and that the original publication in this journal is cited, in accordance with accepted academic practice. No use, distribution or reproduction is permitted which does not comply with these terms. 